medRxiv preprint doi: https://doi.org/10.1101/2021.02.07.21250589; this version posted February 8, 2021. The copyright holder for this preprint (which was not certified by peer review) is the author/funder, who has granted medRxiv a license to display the preprint in perpetuity.

All rights reserved. No reuse allowed without permission.

\title{
Prevention of Diabetic Foot Ulcer in High Risk Patient: The Role of Internist in Providing Adequate Foot Care
}

\author{
Ida Ayu Kshanti, ${ }^{1}$ Nanang Soebijanto, ${ }^{1}$ Nadya Magfira, ${ }^{2}$ Marina Epriliawati, ${ }^{1}$ Jerry \\ Nasarudin, ${ }^{1}$ Md Ikhsan Mokoagow ${ }^{1,3}$ \\ 1. Division of Endocrinology, Metabolism, and Diabetes, Department of Internal \\ Medicine, Fatmawati General Hospital, Jakarta, Indonesia \\ 2. Department of Epidemiology, Faculty of Public Health, Univeristas Indonesia, \\ Jakarta, Indonesia \\ 3. Division of Metabolic Endocrine, Department of Internal Medicine, Faculty of \\ Medicine, Universitas Indonesia, Jakarta, Indonesia
}

\section{Corresponding authors:}

Ida Ayu Kshanti

Department of Internal Medicine. Fatmawati General Hospital. TB Simatupang Street c No.18, RT.4/RW.9, Cilandak Bar., Kec. Cilandak, South Jakarta, Jakarta Province, Indonesia 12430

Email: madeidaayu@yahoo.com

\section{ABSTRACT}

Background and aim: The awareness and practice of diabetes foot prevention by internist through routine examination and patient education remains less than optimal. This study aimed to evaluate the quality of care of internist in performing foot care in high-risk patients.

Methods: A cross sectional study was conducted in a tertiary care hospital in Jakarta, Indonesia. Type 2 diabetes mellitus subjects with high-risk foot complication were included in this study. Each subject filled-in a questionnaire investigating whether they had received information about proper foot care practice and whether they have ever had their feet examined by an internist at their present consultation. Multivariate logistic regression were performed.

Results: 368 patients were recruited, 130 of them (35.3\%) treated by endocrinologists. $71.20 \%$ patients did not received any information on foot care and $54.08 \%$ patients did not received any foot examination. Foot care information was 1.6 times more frequently provided to patient with longer diabetes duration and 2 times more frequently provided to those who had history of diabetic foot ulcer. Meanwhile, foot examination was 1.5 times more frequently provided to those with longer diabetes duration and had a history of Lower Extremity Amputation. Compare to nonendocrinologist internist, endocrinologists tend to provide foot education and perform foot examination 2.2 to 2.5 times more frequently than non-endocrinologists.

Conclusion: Most of patients with high risk foot problems were not offered adequate foot care. It is necessary to develop strategies to improve the care and awareness among health professionals treating patients with diabetes especially internist.

Keywords: Education, Diabetes, Foot Ulcer, Internist, Endocrinologist 
medRxiv preprint doi: https://doi.org/10.1101/2021.02.07.21250589; this version posted February 8, 2021. The copyright holder for this preprint (which was not certified by peer review) is the author/funder, who has granted medRxiv a license to display the preprint in perpetuity.

All rights reserved. No reuse allowed without permission.

\section{Introduction}

It is estimated that one in four people with diabetes will develop a diabetic foot ulcer (DFU) at least once in their life time. ${ }^{1}$ It is also common reason for hospital admission among people with diabetes and may lead to the amputation of the lower limb. A previous study showed that a lower limb is amputated due to diabetes every $30 \mathrm{~s}$, and the average annual cost of diabetic foot is $\$ 8659$ per patient. ${ }^{2}$ In Indonesia, it is estimated that there are 10.3 million people with DM, moreover $8.7 \%$ patients with DM had DFU with amputation rate $1.3 \% .^{3-4}$

It is well established in the literature that diabetes foot disease can be delayed or prevented through foot care. ${ }^{5}$ As recommended by International Working Group On The Diabetic Foot (IWGDF), key elements to prevent foot ulcers are; 1 ) identifying the at risk foot, 2) regularly inspecting and examining at risk foot, 3) foot care education, 4) ensuring appropriate footwear and 5) treating risk factor. ${ }^{6}$ People who were classified as high risk (history of ulceration, amputation, end-stage renal disease) were recommend to get foot screening and examination once every 1-3 months. ${ }^{5}$

Healthcare practitioners especially internists are actually aware of the consequences of diabetic foot. ${ }^{7}$ Unfortunately, the care of diabetic foot and its related condition are from optimal. Very few clinicians are treating the diabetic foot in a systematic, standardized method with proper risk categorization of foot complication. ${ }^{8}$ Auditing of all aspects of the service to ensure that local practice including quality of care of internist meets accepted international standards of care are necessary. ${ }^{7}$

In the context of improving the care of patients presenting with a diabetic foot, this study aimed to evaluate the quality of care of internist in performing foot care especially in high-risk patients.

\section{Methods}

\subsection{Design and Settings}

This is a cross sectional analytical study, which include 368 patients from Fatmawati General Hospital, Jakarta, Indonesia. Subjects were recruited from internal medicine department outpatient clinic between January-December 2016. At that time, in our clinic, there are 2 endocrinologists and 9 non-endocrinologist internists. All patients with type 2 diabetes mellitus will be assessed by endocrinologist once every 3 months, other than that time patient who came to our hospital for diabetes treatment can be seen by different non-endocrinologist internist according to internist on duty.

\subsection{Sampling of patient}

All patient with type 2 diabetes mellitus who had history of diabetic foot ulcer, and or history of low extremity amputation (LEA), and or history of chronic kidney disease (CKD); estimated glomerular filtration rate (eGFR) $\leq 60 \mathrm{~mL} / \mathrm{min}$ were considered eligible for this study. Exclusion criteria for this study were patient with cognitive impairment, or in emergency situation or subjects with abbreviated mental state who cannot independently fill questionnaire. Patient were sampled using consecutive sampling. Ethics approval was obtained from the Ethical Committee for Medical Research, Fatmawati General Hospital. 
medRxiv preprint doi: https://doi.org/10.1101/2021.02.07.21250589; this version posted February 8, 2021. The copyright holder for this preprint (which was not certified by peer review) is the author/funder, who has granted medRxiv a license to display the preprint in perpetuity.

All rights reserved. No reuse allowed without permission.

\subsection{Data collection procedures}

Patient screening was done prior to the study to obtain the list of patients who were consider eligible for this study. These prospective subjects were then queuing in the polyclinic to underwent consultation to internist on duty. All of the internist during study time, were not know whether they patient will become study participants. After clinical assessment and consultation, a research team member will give oral and written information about the study. Patients who were willing to participate in this study were asked to sign a written informed consent.

Afterwards, the patients were asked to self-filled questionnaire investigating whether they had received information about foot care and whether they had had their feet examine by their prior internist during the latest consultation. Foot examination defined as physician perform anamnesis and or physical examination (seen, touch, etc.) to patient. All data concerning general medical history and laboratory data were collected by research member according to patient's medical records and study forms specifically developed by the research committee. All data were transferred into a special clinical report form and were stored in the Integrated Center of Diabetes Care, Fatmawati General Hospital. The forms were checked for duplication before being entered into an electronic database.

\subsection{Statistical analysis}

Patient characteristic according to physician in charge, receiving foot education, performing foot examination were first compared using $x^{2}$ test. To account for the multilevel nature of the data (patients clustered within physician or foot education or foot examination) and to control simultaneously for the possible cofounding effects of the different variables, we used multivariate logistic regression models. Results are expressed as prevalence ratio (PR) with their $95 \%$ confidence interval $(95 \mathrm{Cl})$. In the analysis in correlates of foot education and examination, an $O R>1.0$ indicates a higher likelihood of receiving the information or the examination. All the analysis was performed using STATA Version 12. This study had been approved by ethical committee of Fatmawati General Hospital 021/KPP/XI/2016

\section{Results}

\subsection{Correlates of specialty of internist}

Overall, 368 patients were recruited, of whom 130 (35.33\%) treated by endocrinologist specialist. Among the latter, a previous history of foot ulcers was present in 270 patients (73.37\%), 22 (5.98) had a previous history of LEA, and 158 patients (42.93) had CKD. The overall LEA event was $8.09 \%$ in patient with history of DFU. Patients characteristics according to internist specialty are reported in table 1 . There is no correlation between internist specialty and patients' characteristics.

Table 1. Patient Characteristics According To Internist Specialty

\begin{tabular}{llll}
\hline Variable & \multicolumn{2}{c}{ Internist N (\%) } & PR (95\% Cl) \\
\cline { 2 - 3 } & Endocrinologist & Non-endocrinologist & \\
\hline Sex & & \\
Male & $66(34.92)$ & $123(65.08)$ & $0.98(7.4-1.29)$ \\
Female & $64(35.75)$ & $115(64.25)$ & \\
\hline
\end{tabular}


medRxiv preprint doi: https://doi.org/10.1101/2021.02.07.21250589; this version posted February 8, 2021. The copyright holder for this preprint (which was not certified by peer review) is the author/funder, who has granted medRxiv a license to display the preprint in perpetuity.

All rights reserved. No reuse allowed without permission.

\begin{tabular}{|c|c|c|c|}
\hline \multicolumn{4}{|l|}{ Age } \\
\hline$\geq 60$ years & $77(37.56)$ & $128(62.44)$ & $1.19(0.89-1.58)$ \\
\hline$<60$ years & $51(31.68)$ & $110(68.32)$ & \\
\hline \multicolumn{4}{|c|}{ School education } \\
\hline$\leq 12$ years & $94(37.60)$ & $156(62.40)$ & $1.28(0.93-1.78)$ \\
\hline$>12$ years & $34(29.31)$ & $82(70.69)$ & \\
\hline \multicolumn{4}{|c|}{ Diabetes duration } \\
\hline$\geq 10$ years & $65(32.99)$ & $132(67.01)$ & $0.88(0.66-1.16)$ \\
\hline$<10$ years & $64(37.65)$ & $106(62.35)$ & \\
\hline \multicolumn{4}{|l|}{$\mathrm{BMI}$} \\
\hline$\geq 25 \mathrm{~kg} / \mathrm{m} 2$ & $43(36.75)$ & $74(63.25)$ & $1.18(0.83-1.70)$ \\
\hline$<25 \mathrm{~kg} / \mathrm{m} 2$ & $36(31.03)$ & $80(68.97)$ & \\
\hline \multicolumn{4}{|l|}{ FBG } \\
\hline$\geq 110 \mathrm{~g} / \mathrm{dL}$ & $84(35.74)$ & $151(64.26)$ & $1.04(0.77-1.41)$ \\
\hline$<110 \mathrm{~g} / \mathrm{dL}$ & $40(34.48)$ & $76(65.52)$ & \\
\hline \multicolumn{4}{|l|}{ History of DFU } \\
\hline Yes & $99(36.40)$ & $173(63.60)$ & $1.13(0.81-1.57)$ \\
\hline No & $31(32.29)$ & $65(67.71)$ & \\
\hline \multicolumn{4}{|l|}{ History of LEA } \\
\hline Yes & $7(31.82)$ & $15(68.18)$ & $0.90(0.48-1.68)$ \\
\hline No & $123(35.55)$ & $223(64.45)$ & \\
\hline \multicolumn{4}{|l|}{ CKD } \\
\hline Yes & $48(30.38)$ & $110(69.62)$ & $0.78(0.58-1.04)$ \\
\hline No & $82(39.05)$ & $128(60.95)$ & \\
\hline
\end{tabular}

\subsection{Foot care education}

Seventy one percent of the patient declared that they had not received any information about foot care during consultation. the proportion of patients receiving foot education according to sociodemographic and clinical characteristics are reported in table 2. Information on foot care was more frequently provided in patient who were assessed by endocrinologist, those with longer diabetes duration and those who had history of DFU.

Table 2. Foot education according to patient characteristics

\begin{tabular}{|c|c|c|c|c|}
\hline \multirow[t]{4}{*}{ Variable } & \multicolumn{2}{|c|}{ Education N (\%) } & \multirow{4}{*}{$\begin{array}{l}\text { Crude PR } \\
(95 \% \mathrm{Cl})\end{array}$} & \multirow{4}{*}{$\begin{array}{l}\text { Multilevel PR } \\
(95 \% \mathrm{Cl})\end{array}$} \\
\hline & Yes & No & & \\
\hline & $N=106$ & $\mathrm{~N}=262(71.20)$ & & \\
\hline & $(28.80)$ & & & \\
\hline \multicolumn{5}{|l|}{ Specialization } \\
\hline Endocrinologist & $61(46.92)$ & $69(53.08)$ & $2.48(1.80-3.42)$ & $2.50(1.83-3.41)$ \\
\hline Non-endocrinologist & $45(18.91)$ & $193(81.09)$ & & \\
\hline \multicolumn{5}{|l|}{ Sex } \\
\hline Male & $55(29.10)$ & $134(70.90)$ & $1.02(0.74-1.41)$ & \\
\hline Female & $51(28.49)$ & $128(71.51)$ & & \\
\hline \multicolumn{5}{|l|}{ Age } \\
\hline$\geq 60$ years & $56(27.32)$ & $149(72.68)$ & $0.90(0.65-1.24)$ & \\
\hline$<60$ years & $49(30.43)$ & $112(69.57)$ & & \\
\hline \multicolumn{5}{|l|}{ School education } \\
\hline$\leq 12$ years & $74(29.60)$ & $176(70.40)$ & $1.28(0.93-1.78)$ & \\
\hline$>12$ years & $32(27.59)$ & $84(72.41)$ & & \\
\hline
\end{tabular}


medRxiv preprint doi: https://doi.org/10.1101/2021.02.07.21250589; this version posted February 8, 2021. The copyright holder for this preprint (which was not certified by peer review) is the author/funder, who has granted medRxiv a license to display the preprint in perpetuity.

All rights reserved. No reuse allowed without permission.

\begin{tabular}{|c|c|c|c|c|}
\hline \multicolumn{5}{|c|}{ Diabetes duration } \\
\hline$\geq 10$ years & 65 (32.99) & $132(67.01)$ & \multirow[t]{2}{*}{$1.07(0.76-1.52)$} & \multirow[t]{2}{*}{$1.59(1.17-2.16)$} \\
\hline$<10$ years & $40(23.53)$ & $130(76.47)$ & & \\
\hline \multicolumn{5}{|l|}{$\mathrm{BMI}$} \\
\hline$\geq 25 \mathrm{~kg} / \mathrm{m} 2$ & $45(38.46)$ & $72(61.54)$ & \multirow[t]{2}{*}{$1.21(0.85-1.71)$} & \\
\hline$<25 \mathrm{~kg} / \mathrm{m} 2$ & $37(31.90)$ & $79(68.10)$ & & \\
\hline \multicolumn{5}{|l|}{ FBG } \\
\hline$\geq 110 \mathrm{~g} / \mathrm{dL}$ & $65(27.66)$ & $170(72.34)$ & \multirow[t]{2}{*}{$0.89(0.63-1.25)$} & \\
\hline$<110 \mathrm{~g} / \mathrm{dL}$ & $36(31.03)$ & $80(68.97)$ & & \\
\hline \multicolumn{5}{|l|}{ History of DFU } \\
\hline Yes & $90(33.09)$ & $182(66.91)$ & \multirow[t]{2}{*}{$1.99(1.23-3.20)$} & \multirow[t]{2}{*}{$1.97(1.25-3.11)$} \\
\hline No & $16(16.67)$ & $80(83.33)$ & & \\
\hline \multicolumn{5}{|l|}{ History of LEA } \\
\hline Yes & $4(18.18)$ & $18(81.82)$ & \multirow[t]{2}{*}{$0.62(0.25-1.52)$} & \\
\hline No & $102(29.48)$ & $244(70.52)$ & & \\
\hline \multicolumn{5}{|l|}{ CKD } \\
\hline Yes & $42(26.58)$ & $116(73.42)$ & \multirow[t]{2}{*}{$0.87(0.63-1.21)$} & \\
\hline No & $64(30.48)$ & $146(69.52)$ & & \\
\hline
\end{tabular}

\subsection{Foot Examination}

Overall, 169 patients (45.92\%) declared that they prior internist had performed foot examination to them, while 199 (54.08\%) declared that they had never received any foot examination according to their last consultation. The proportion of patient receiving foot examination according to sociodemographic, clinical characteristics and physician in charged are reported in table 3. Foot examination was more likely to performed in patient with longer diabetes duration and those who had history of LEA. Moreover, endocrinologist was more frequently perform foot examination compared to non-endocrinologist internist.

Table 3. Foot examination according to patient charateristics

\begin{tabular}{|c|c|c|c|c|}
\hline \multirow[t]{4}{*}{ Variable } & \multicolumn{2}{|c|}{ Foot Examination $\mathrm{N}(\%)$} & \multirow{4}{*}{$\begin{array}{l}\text { Crude PR } \\
(95 \% \mathrm{Cl})\end{array}$} & \multirow{4}{*}{$\begin{array}{l}\text { Multilevel PR }(95 \% \\
\mathrm{Cl})\end{array}$} \\
\hline & Yes & No & & \\
\hline & $N=169$ & $N=199$ & & \\
\hline & $(45.92)$ & $(54.08)$ & & \\
\hline \multicolumn{5}{|l|}{ Specialty } \\
\hline Endocrinologist & $61(46.92)$ & $69(53.08)$ & $2.48(1.80-3.42)$ & $2.19(1.79-2.69)$ \\
\hline Non-endocrinologist & 45 (18.91) & $193(81.09)$ & & \\
\hline \multicolumn{5}{|l|}{ Sex } \\
\hline Male & $94(49.74)$ & $95(50.26)$ & $1.19(0.95-1.49)$ & \\
\hline Female & $75(41.90)$ & $104(58.10)$ & & \\
\hline \multicolumn{5}{|l|}{ Age } \\
\hline$\geq 60$ years & $99(48.29)$ & $106(51.71)$ & $1.13(0.90-1.42)$ & \\
\hline$<60$ years & $69(42.86)$ & $92(57.14)$ & & \\
\hline \multicolumn{5}{|l|}{ School education } \\
\hline$\leq 12$ years & $113(45.20)$ & $137(54.80)$ & $0.95(0.75-1.21)$ & \\
\hline$>12$ years & $55(47.41)$ & $61(52.59)$ & & \\
\hline \multicolumn{5}{|l|}{ Diabetes duration } \\
\hline$\geq 10$ years & $103(52.28)$ & $94(47.72)$ & $1.37(1.08-1.73)$ & $1.45(1.20-1.75)$ \\
\hline$<10$ years & $65(38.24)$ & $105(61.76)$ & & \\
\hline \multicolumn{5}{|l|}{ BMI } \\
\hline$\geq 25 \mathrm{~kg} / \mathrm{m} 2$ & 62 (52.99) & $55(47.01)$ & $1.23(0.94-1.61)$ & \\
\hline$<25 \mathrm{~kg} / \mathrm{m} 2$ & $50(43.10)$ & $66(56.90)$ & & \\
\hline \multicolumn{5}{|l|}{ FBG } \\
\hline$\geq 110 \mathrm{~g} / \mathrm{dL}$ & $112(47.66)$ & $123(47.55)$ & $1.06(0.83-1.36)$ & \\
\hline
\end{tabular}


medRxiv preprint doi: https://doi.org/10.1101/2021.02.07.21250589; this version posted February 8, 2021. The copyright holder for this preprint (which was not certified by peer review) is the author/funder, who has granted medRxiv a license to display the preprint in perpetuity.

All rights reserved. No reuse allowed without permission.

\begin{tabular}{lcccc}
\hline$<110 \mathrm{~g} / \mathrm{dL}$ & $52(44.83)$ & $64(55.17)$ & & \\
History of DFU & & & & \\
$\quad$ Yes & $132(48.53)$ & $140(51.47)$ & $1.26(0.95-1.67)$ & \\
$\quad$ No & $37(38.54)$ & $59(61.46)$ & & \\
$\begin{array}{l}\text { History of LEA } \\
\quad \text { Yes }\end{array}$ & $11(50.00)$ & $11(50.00)$ & $1.10(0.71-1.69)$ & $1.45(1.29-1.62)$ \\
$\quad$ No & $158(45.66)$ & $188(54.34)$ & & \\
CKD & & & & \\
$\quad$ Yes & $75(47.47)$ & $183(52.53)$ & $1.06(0.85-1.32)$ & \\
$\quad$ No & $94(44.76)$ & $116(55.24)$ & & \\
\hline
\end{tabular}

\section{Discussion}

To our knowledge, this is the first study evaluating internist' practice towards foot care in individual with Type 2 Diabetes Mellitus in Indonesia especially in high risk patient. Our data show that internist attention to foot problems in high-risk diabetes patient is generally low, there are substantial proportion of patients who are not offered adequate foot care. In our findings about seventy percent of the high-risk patients did not received foot educations and most of them were treated by non-endocrinologist. The only patient characteristics associated with greater chance of giving foot education in our study was longer diabetes durations and history of DFU. People with longer diabetes duration (> 10 years) are at risk of developing foot ulcers, also a person with history of foot ulcer are at higher risk to develop recurrent foot ulcer. ${ }^{9-11}$ Therefore, author thought that attention to this particular person by internist are much higher. Same gloomy picture emerges when looking at internist practice, in our study only $45.92 \%$ of such patients had their feet examined during consultation, and most of the patients who were not examined were treated by non-endocrinologist. In line with our findings, a study from Italia showed that endocrinologist was performed significantly better in terms of foot examination compared to another physician. ${ }^{12}$ Also, those patients who received foot education and those who had their foot examined were at lower risk of not regularly checking their feet. Based on IWGDF recommendation, every person with diabetes should be examine annually for signs and symptoms of foot disease. ${ }^{13}$ Also, education should be given as it improves a patient's foot self-care knowledge and self-protective behavior. ${ }^{5}$

Finally, some of the potential limitations of our study need to be discussed. First, patients were selected through consecutive sampling, this sampling methods could not be considered as representatives of the entire population. Second, in nonendocrinologist specialist, there are particularly among internist, who were more interested in diabetes care and in the training to become endocrinologist therefore they may not reflect the diabetes care delivered by non-endocrinologist.

\section{Conclusion}

It is important to increase among internist, the awareness for the prevention of diabetic foot. It is necessary to develop strategies to improve the care and awareness among health professional especially internist in treating patients with diabetes.

\section{Acknowledgment}

The author wishes to acknowledge dr. Nissa, and dr. Kevin for their contribution to data acquisition. 
medRxiv preprint doi: https://doi.org/10.1101/2021.02.07.21250589; this version posted February 8, 2021. The copyright holder for this preprint (which was not certified by peer review) is the author/funder, who has granted medRxiv a license to display the preprint in perpetuity.

All rights reserved. No reuse allowed without permission.

\section{Reference:}

1. Matilde M, Russell D, Boyko EJ, Jefcoate W, Mills JI, Morbach S, et al. IWGDF Guideline on the classification of diabetic foot ulcers [Internet]. 2019. Available from: https://iwgdfguidelines.org/wp-content/uploads/2019/05/07-IWGDFclassification-guideline-2019.pdf

2. Z Zhang P, Lu J, Jing Y, Tang S, Zhu D, Bi Y. Annals of Medicine Global epidemiology of diabetic foot ulceration?]: a systematic review and meta-analysis. 2017;3890.

3. International Diabetes Federation. IDF Diabetes Atlas Eighth Edition 2017. International diabetes federation. 2017. 1-150 p.

4. Center for Data and Information Ministry of Health Republic of Indonesia (Pusdatin Kemenkes RI). Diabetes Situation and Analyses (in Indonesian). Pusdatin Kemenkes RI. 2014.

5. Bus SA, Lavery LA, Soares MM, Rasmussen A, Raspovic A, Sacco ICN, et al. IWGDF Guideline on the prevention of foot ulcers in persons with diabetes [Internet]. 2019. Available from: https://iwgdfguidelines.org/wpcontent/uploads/2019/05/02-IWGDF-prevention-guideline-2019.pdf

6. Schaper C, Van Netten JJ, Apelqvist J, Bus SA, Hinchliffe RJ, Lipsky BA. IWGDF Practical guidelines on the prevention and management of diabetic foot disease [Internet]. 2019. Available from: https://iwgdfguidelines.org/wpcontent/uploads/2019/05/01-IWGDF-practical-guidelines-2019.pdf

7. Cheung C, Queen D. The diabetic foot: A reconceptualization Comment. Diabet foot canada. 2013;1(1):11-2.

8. Ibrahim A. IDF Clinical Practice Recommendation on the Diabetic Foot: A guide for healthcare professionals. Vol. 127, Diabetes Research and Clinical Practice. 2017. 285-287 p.

9. Younis B Bin, Shahid A, Arshad R, Khurshid S, Ahmad M, Yousaf H. Frequency of foot ulcers in people with type 2 diabetes, presenting to specialist diabetes clinic at a Tertiary Care Hospital, Lahore, Pakistan. BMC Endocr Disord. 2018;18(1):16.

10. Almobarak AO, Awadalla $\mathrm{H}$, Osman $\mathrm{M}$, Ahmed $\mathrm{MH}$. Prevalence of diabetic foot ulceration and associated risk factors: An old and still major public health problem in Khartoum, Sudan? Ann Transl Med. 2017;5(17):1-7.

11. Fawzy MS, Alshammari MA, Alruwaili AA, Alanazi RTR, Alharbi JAM, Almasoud $A M R$, et al. Factors associated with diabetic foot among type 2 diabetes in Northern area of Saudi Arabia: A descriptive study 11 Medical and Health Sciences 1103 Clinical Sciences 11 Medical and Health Sciences 1117 Public Health and Health Services. BMC Res Notes [Internet]. 2019;12(1):1-7. Available from: https://doi.org/10.1186/s13104-019-4088-4

12. De Berardis G, Pellegrini F, Franciosi M, Belfiglio M, Di Nardo B, Greenfield S, et al. Are Type 2 diabetic patients offered adequate foot care? The role of physician and patient characteristics. J Diabetes Complications. 2005;19(6):31927.

13. Lipsky B, Aragon SJ, Diggle M, Embil J, Kono S, Lavery L, et al. IWGDF Guidance on the diagnosis and management of foot infections in persons with diabetes on the Diabetic Foot IWGDF Guidance on the diagnosis and management of foot infections in persons with diabetes on the Diabetic Foot. Prep by Int Work Gr Diabet Foot . 2015; 
medRxiv preprint doi: https://doi.org/10.1101/2021.02.07.21250589; this version posted February 8, 2021. The copyright holder for this preprint

(which was not certified by peer review) is the author/funder, who has granted medRxiv a license to display the preprint in perpetuity.

All rights reserved. No reuse allowed without permission. 